\title{
Regionalisation in Romania: A Game between Centralism and Regionalism
}

\author{
Hunor BaJTALAN, Cluj-Napoca*
}

with 10 figures and 1 table in the text

\section{Content}

Summary 239

1 Introduction...

2 The origins of the regional concept in Romania

3 Centralism vs. regionalism: the evolution of the administrative-territorial organisation of modern Romania

4 Conclusions

5 References

\section{Summary}

The processes leading to international collaborations and supranational integration projects, as well as the reappearance of meso-level territorial structures, namely 'regions', have swept across Europe and beyond. In this respect it is not surprising at all that in the last two/three years the question of administrative-territorial reform has become one of the most widely debated, most mediatised issues of the general public in Romania, especially after the determination of the former ruling coalition, the Social-Liberal Union to push through 2013 (in one year!) a thorough and comprehensive reform of regionalisation and decentralisation. Although from the public to the academic and political spheres a wide debate emerged, yet instead of an in-depth comprehensive analysis of the question of administrative-territorial reform in Romania, the societal discourse was mainly catalysed around the superficial studies and models proposed by various political stakeholders. This process mainly resulted in

* Hunor BaJtalan, PhD. student, Department of Geography in Hungarian, Faculty of Geography, Babeș-Bolyai University, Strada Clinicilor 5-7, RO-400006 Cluj-Napoca, Romania; email: bajtalan.hunor@gmail.com 
the frequent publication of several maps presenting the new administrative-territorial structure of Romania, very often generating heated, but superficial public debates. Unfortunately, the negative aspects of the public debate were also mainly true in the case of the government-backed reform project, which in the middle of superficiality and hasty preparation it is not surprising at all that it ended up in failure.

In this respect of course the following article doesn't and cannot provide answers to all of the above-outlined problems, yet it can be interpreted more like a reflective undertaking, which through its specific space-time perspective analyses the question of regionalisation from the establishment of the first seeds of administrativeterritorial organisation of the Romanian nation state until present-day Romania, with a special focus on recent regionalisation discourses and projects in Romania. This unique historic-geographical perspective, as well as the analysis of the heritage of the past clearly brings into new light the question of administrative-territorial reform of nowadays Romania.

\section{Introduction}

Almost a decade has passed since Romania joined to the European family of nations and already it is almost impossible to find an aspect of our daily lives that hasn't been influenced by this historical process. Overall through the transfer of political and organisational cultures, development models, as well as institutional practices the European Union (EU) significantly restructured not just the socio-economic and political climate in Romania, but also influenced the reorganisation of the geographical space. From this, the question of region building doesn't constitute an exception. However, we have to clarify that, as we shall see, the regional discourse in Romania although it came through a 'European channel', yet in reality is largely underpinned by much more profound processes. Among others growing social and economic disparities, the overpopulation of the planet, climate change, as well as the everdeepening globalisation confront today's societies with such forces and provocations that are reshaping the very foundations of our social and spatial organisation.

According to Loughuin et al. (2010) these global challenges as well as the appearance of a more and more borderless, 'porous' world has 'relativised' the traditional position of the nation-state by undermining its authority, with the slow transfer of national sovereignty over to supranational organisations. On the other side a subnational level is also emerging as a result of the aspiration for greater autonomy and self-determination of the constituent elements of the nation state (KEATING 2009). Therefore this is the broader picture in which we incorporate recently emerging processes of state devolution and territorial reorganisation. Throughout the European Union we see a surge in regionalist, localist or place-based agendas, from which Romania doesn't constitute an exception. 
In the light of these trends the aim of the following paper is to analyse the process of region building in Romania, especially in the context of recent initiatives towards the administrative-territorial reorganisation of the state. In this respect one of the main starting presumptions is that through its history Romania, mainly due to its heterogeneity and cultural diversity was always in constant flux between bottomup initiatives of regionalism and top-bottom oriented forces of centralisation. This duality left its imprint not just on the evolution of the organisational culture of the state administration, but also influences current movements towards the establishment of the meso-level in Romania. Therefore the article through a geographic lens specifically addresses the role of the heritage of the past in current processes of spatial restructuring and reorganisation.

\section{The origins of the regional concept in Romania}

Recently, regions have become frequent, recurring topics in our social and scientific debates, despite the fact that the cohesion forces leading to these sociospatial phenomena are not nowaday's specialties. With the appearance of the very first human communities appeared those factors that binded them together into unique socio-spatial structures along various centripetal forces. In this context regions can be interpreted as time- and space-specific social constructions in perpetual transformation for the spatial organisation of our societies (Allen et al. 1998; BENEDEK 2004; NemesNaGy 2009; Tomaney 2009; PAasi 2009, 2010, 2011, 2013).

In Romania, the existence of a fragmented physical environment, a unique structure of socio-spatial interrelationships, added to this a diverging culturalhistorical heritage at the crossroads of Western, Eastern and Southeastern Europe, resulted in the emergence of a diversified geographical space from the local to the regional and national level (SĂgeată 2006; Murgescu 2010; Boia 2012; Duuvara 2012). In Romania as in many countries around the world, the basic fundamental unit for the spatial organisation of the society was represented by the village community (FilitTi 1929). This is confirmed by one of the most renowned personalities of the Romanian interbellum period, by the philosopher, writer and poet Lucian BLAGA, who in one of his most influential works Spațiul Mioritic ('mioritic space') defined the Romanian national identity or 'Romanianness' through a combination of environment and culture. In his vision the 'plai' (the slope of a hill, usually covered by meadows), the idyllic natural space of the Romanian folk ballads, especially the popular 'Miorița' represented more than a natural, topographic space, it can be regarded as the cradle of the Romanian culture and national identity. In this respect he viewed the rural landscape of Romania as the guardian of Romanian cultural specificity, as the space of organic existence (BlagA 1969; LovatT 1999). 
These early, primordial settlements had the fundamental role to ensure the survival of native communities, to protect their identity and consolidate their culturalhistorical heritage by the institutionalisation of these structures under the protective umbrella of the community. These first structures of socio-spatial cohesion contributed to the formation of larger territorial units mainly along the administrative-territorial organisation of the society, broader economic possibilities and the need for stronger protective authorities. Therefore these pre-state communities near their basic function of social organisation are empowered with administrative, economic, cultural and defensive ones resulting also in their territorial growth (BUCUR 2012).

In this respect at the meso-level, one of the most fascinating entities of the Romanian geographical space are represented by the existence of the so-called țări (approximate translation would be 'lands'). These lands, regions are not only unique to Romania, because under various terms the phenomenon exists in different parts of the world. Just mention the English shire, the French pays, the German Gau ${ }^{1}$, the Italian paese, the Slavic župa and the term becomes understandable. The emergence of these territorial entities is strongly related to the existence of a fragmented geographical space, with well-defined natural boundaries, like mountain ranges, hardly penetrable rivers and vegetation resulting in the difficulty to maintain relationships. Therefore these spatial entities through their cultural-historical cohesion, their specific identity represent the natural evolution of the village communities and village unions along a socio-spatial framework (CViJIĆ 1918; Conea 1938; Bucur 2012).

The true meso-level in Romania - geographically speaking - emerged with the formation of the early administrative-political units, namely duchies (ducate)/ voievodeships (voievodate), principalities (cnezate) and the institutionalisation of several țări during medieval times $\left(11^{\text {th }}-14^{\text {th }}\right.$ century). These early formations later were incorporated and ultimately dissoluted into the principalities of Wallachia [Țara Românească], Moldova and Transylvania [Ardeal]. The whole evolution of the region is strongly connected to its ethnical and cultural diversity, to its position at the crossroads of several great powers, namely the Hungarian, Ottoman, Habsburg and Russian Empires.

The traditional administrative-territorial unit of Wallachia was the sudstvo, the Slavic equivalent term of the current județ (approximate translation would be 'jurisdiction', 'county') represented by the pârcălab with administrative and judicial functions, while in Moldova the ținut/volost (approximate translation would be 'lands') was the bottom of the administration governed by the same institution of the parcălab

\footnotetext{
$1 \quad$ Hereby the term Gau should be interpreted in its medieval sense, representing a cultural landscape similar to the English shire or the French pays and should not be confused with the term revived in the 1920s during Nazi Germany, when the Gau was the main administrativeterritorial unit of Germany.
} 
with the same functions. Transylvania with the rest of the Hungarian Kingdom was organised into counties (vármegye) governed by the county head (várispán) who was the representative of the king, having the same judiciary functions as their Romanian counterparts in the principalities. Near the county system, several parts of Transylvania along the regions inhabited by the Székelys and the Transylvanian Saxons was organised into privileged seats (szék) with strong administrative-territorial autonomy (Filitti 1929; Köpeczi 1987; Nistor 2000; Egyed 2006; KovÁcs 2011; Romsics 2011; DuUvara 2012; Bucur 2012).

Figure 1: Historical regions of Greater Romania (1918-1940)

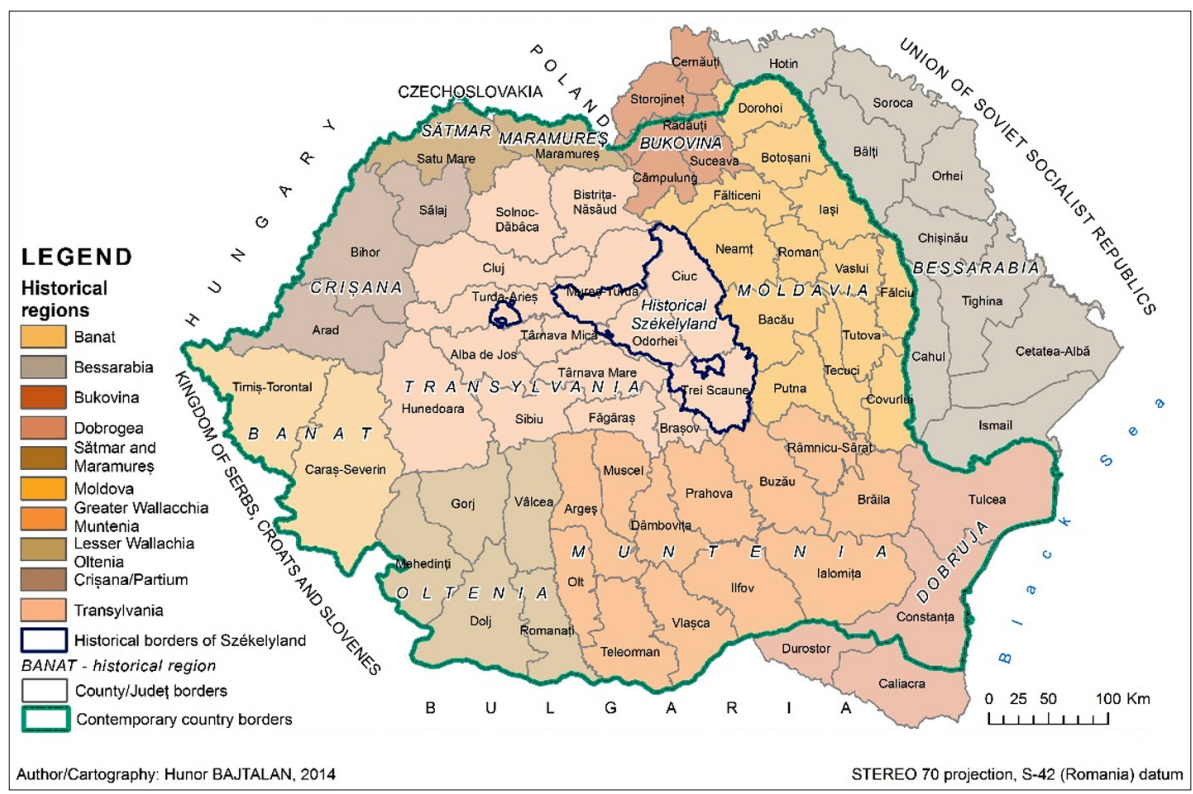

Sources: CovĂSNIANU 2011; Hitchins 2013a, 2013b; 'UNIREA' CARTOGRAPHIC Institute 1922; ESRI HDR100

This ethnical and political diversity of Wallachia, Moldova and Transylvania contributed greatly to the formation of current regional identities across Romania. Therefore the analysis of the regional concept in Romania needs a holistic approach, where regions as social constructs reflect the interrelationships between space, time and society. 


\section{Centralism vs. regionalism: the evolution of the administrative-territorial organisation of modern Romania}

\subsection{The birth of Romania and the first steps in the administrative- territorial organisation (1859-1914)}

The centuries-old Habsburg-Ottoman-Russian rivalry for the Central European and the Balkan region during the $19^{\text {th }}$ century was finally coming to an end, at the expense of the strengthening of the Habsburg dominance and the weakening of the Ottoman Empire in the region. The imperial quest of Europe's Great Powers for the territories of the declining Ottoman Empire gave birth to those circumstances, under which in the ethnically diverse Balkans self-determination movements could emerge. For Romania this process in 1859 resulted in the union of the Principalities of Wallachia and Moldova (Danubian Principalities) first under the suzerainty of the Ottoman Empire, later gaining total independence along with several Balkan states in 1877 during the Russian-Ottoman War (1877-1878) (BARraclough 1992; Kocsis 2007; KovÁcs 2011; Boia 2012; DuUvara 2012).

Figure 2: Territorial evolution and administrative-territorial division of Romania 1862-1913

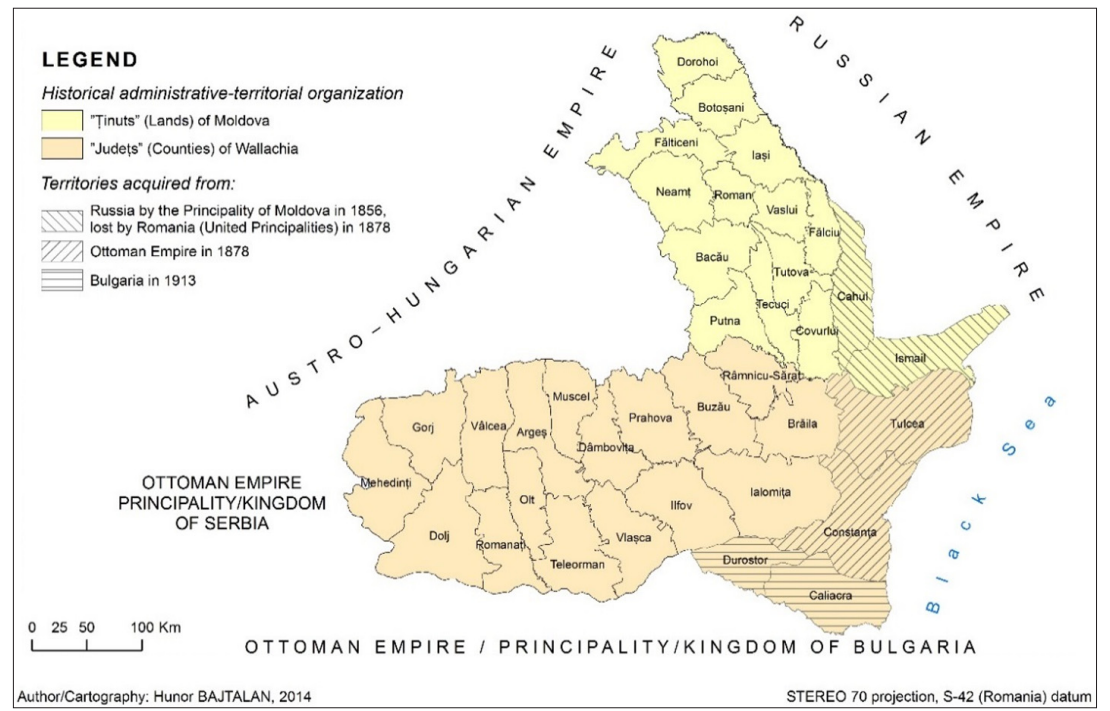

Sources: Charta României Meridionale 1864; Rand McNally 1897; LaW for county Councils 1894; Andree \& Scobel 1905; Groza et al. 2008; Covăsnianu 2011; Hitchins 2013b; ESRI HDR 100 
Following the establishment of the new unified state - from 1862 onwards called Romania - one of the first steps of the reign of Alexandru Ioan Cuza was to harmonise and merge the administration and territorial organisation of the two principalities. In this respect the first project was presented by the first Prime Minister of Romania Barbu Catargiu on the $19^{\text {th }}$ of March 1862 (FILITTI 1929). His project, among others, proposed the adaptation of the județ - county level - administrative-territorial unit of Wallachia over the ținut of Moldova to the whole territory of Romania. But the most controversial part of his proposal was the decentralisation of state powers through the creation of four administrative-territorial regions (general prefectures), mainly along the historical provinces of the two principalities (FilitTi 1929).

The Catargiu project was received with great controversy among the Romanian elite of the time. It was assumed that the proposal was very dangerous to the hardly achieved unity, because through its regionalist approach could ignite the emergence of centrifugal forces, resulting in the fragmentation of the state. Therefore centralism triumphed over regionalism and the administrative-territorial unification of the two principalities materialised on the $2^{\text {nd }}$ of April 1864 with the adoption of the County Council Law No. 396, which introduced the county [județ] as the basic unit for administration throughout Romania (see Fig. 2). The law was in force for 61 years although with several modifications - until the $14^{\text {th }}$ of June 1925, when it was replaced by the administrative unification law (Nistor 2000; SĂgeată 2006; KovÁcs 2011; SĂGEATĂ 2012).

\subsection{The interwar period: between centralism and regionalism (1918- 1940)}

The First World War ended with several consequences to the Central European and the Balkan region, among others the dissolution of the Great Empires and the emergence of the nation states. The favourable political climate brought to Romania the much awaited unification with Bessarabia ( $9^{\text {th }}$ of April 1918), Bucovina ( $9^{\text {th }}$ of November 1918) and Transylvania in the wider sense [Transilvania] on the $1^{\text {st }}$ of December 1918 (Great Union) (Köpeczi 1987; Săgeată 2006; Kocsis 2007; Duuvara 2012; Hitchins 2013b). Therefore after the First World War a new, much more heterogeneous, mosaiclike Romania emerged on the political map of Europe imposing serious challenges for the ruling elite of that time.

First and foremost the biggest provocation constituted the integration and consolidation of the newly acquired territories among a redefined Romanian unitary, nation state, especially if we take into consideration that there were significant territorial and socio-economic disparities (see Table 1, Fig. 3), not to mention the ethnical heterogeneity of the country (BENEDEK \& KuRKó 2010a, 2010b, 2011; MuRgESCU 2010; Hitchins 2013b). According to the national census conducted in the interwar period (1930), the percentage of the nation-building ethnic group, those of the Romanians 
decreased from $92.2 \%$ before the First World War to $71.9 \%$ among the new state territory. Therefore national minorities constituted $28.1 \%$ of the total population in 1930, the principal minorities being from Transylvania, the Hungarians (Székelys and Magyars) $(1,425,000)$, followed by the Transylvanian Saxons/Germans $(745,000)$ and the Jewish communities $(728,000)$.

Near the advantages, the unification also brought several unresolved issues, among others the integration of the new state territories into a common administrative system. In this respect we have to mention that between 1918 and 1925, until the introduction of the law of administrative unification (14 ${ }^{\text {th }}$ of June 1925) Romania functioned with four distinct administrative systems as the legacy of the four different political systems to which Romanian territories belonged:

- The county (vármegye) system of Transylvania in the wider sense based on the administrative organisation of the Hungarian Kingdom;

- The district (Bezirk) system of Bucovina based on the administrative organisation of the Austrian lands of the Habsburg Empire;

- The ținut-based administrative system of Bessarabia largely modified by the Russian occupation of the region;

- The județ-based administrative system of Romania (NISTOR 2000; KovácsCziprián \& Kozma 2003; Săgeatã 2006; Covăsnianu 2011; Elekes 2011).

Table 1: Disparities in Greater Romania 1918-1925

\begin{tabular}{|l|r|r|r|r|r|}
\hline \multicolumn{1}{|c|}{ Historical province } & \multicolumn{1}{c|}{$\begin{array}{c}\text { Area } \\
\left(\mathbf{k m}^{2}\right)\end{array}$} & Population & $\begin{array}{c}\text { Number } \\
\text { of județs }\end{array}$ & $\begin{array}{c}\text { Average } \\
\text { area/județ } \\
\left(\mathbf{k m}^{2}\right)\end{array}$ & $\begin{array}{c}\text { Average } \\
\text { population/ } \\
\text { județ }\end{array}$ \\
\hline Banat & 18,715 & 968,948 & 2 & $9,357,6$ & 484,474 \\
\hline Bessarabia & 44,422 & $1,935,412$ & 9 & $4,935,8$ & 215,046 \\
\hline Bucovina & 10,442 & 807,262 & 11 & 949,3 & 73,387 \\
\hline Crișana & 23,148 & $1,485,835$ & 4 & 5787 & 371,459 \\
\hline Dobruja [Dobrogea] & 23,262 & 662,000 & 4 & $5,818,5$ & 165,500 \\
\hline Maramureș & 3,381 & 145,436 & 1 & 3381 & 145,436 \\
\hline Moldova & 38,058 & $2,131,527$ & 13 & $2,927,5$ & 163,964 \\
\hline $\begin{array}{l}\text { Muntenia } \\
\text { (Greater Wallachia) }\end{array}$ & 52,505 & $3,297,139$ & 11 & $4,773,2$ & 299,740 \\
\hline $\begin{array}{l}\text { Oltenia } \\
\text { (Lesser Wallachia) }\end{array}$ & 24,078 & $1,414,737$ & 6 & $4,013,2$ & 235,790 \\
\hline Transylvania & 57,038 & $2,660,746$ & 15 & $3,802,5$ & 177,383 \\
\hline ROMANIA & $\mathbf{2 9 5 , 0 4 9}$ & $\mathbf{1 5 , 5 0 9 , 0 4 2}$ & $\mathbf{7 6}$ & $\mathbf{3 8 8 2 , 2}$ & $\mathbf{2 0 4 , 0 6 6}$ \\
\hline
\end{tabular}

Sources: Nistor (2000); SăGEATă (2006) with modifications 
Figure 3: Territorial acquisitions of Romania before and during World War I

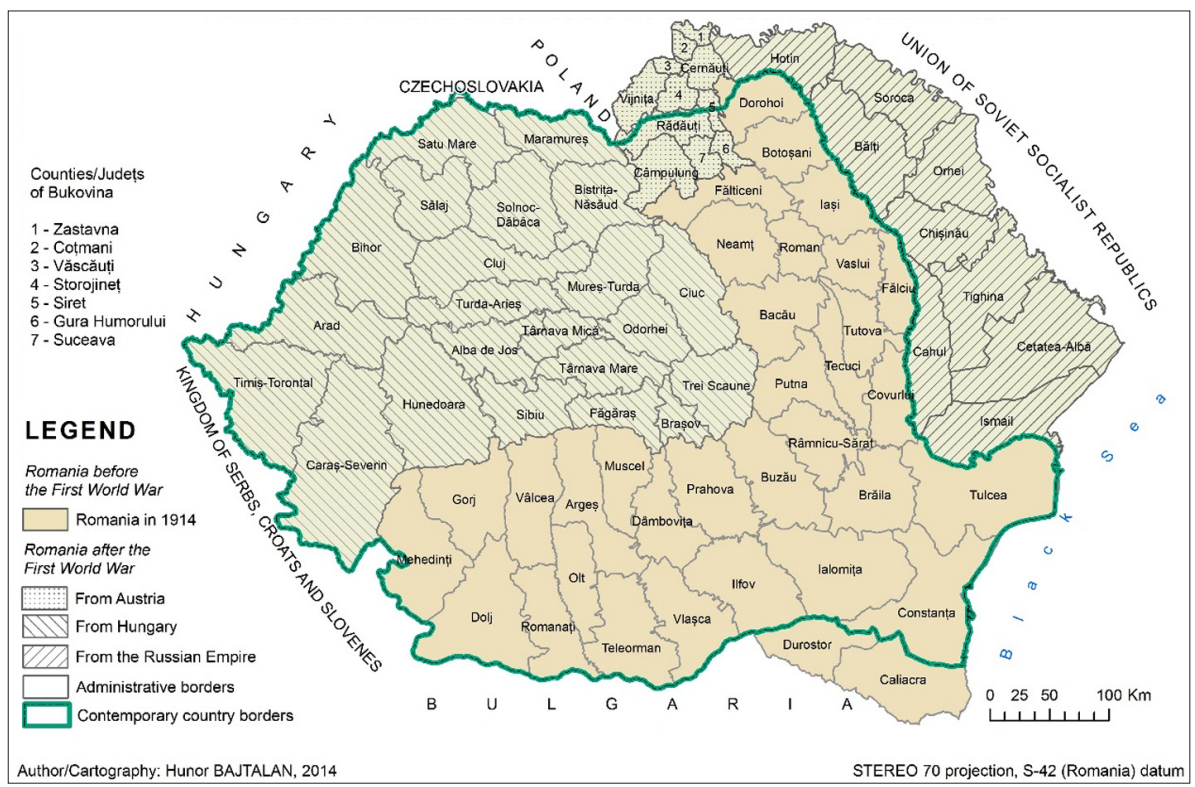

Sources: LAW FOR COUNTY COUNCILS 1894; DeCREE No. 3632, 852, \& 3715 from 1918; 'UNIREA' Cartographic Institute 1922; Bartholomew 1922; Groza et al. 2008; Covăsnianu 2011; HITCHINS 2013b

The administrative discrepancies of a diversified system gradually became untenable and urged the introduction of a comprehensive administrative-territorial reform. In the former territories of the Austro-Hungarian Monarchy a highly decentralised system was in place, where every village constituted a commune, while municipalities had administrative autonomy. The overall local structure had the necessary financial resources to sustain their daily activities and central tutelage wasn't so common and strongly exercised as in the Romanian Old Kingdom. ${ }^{2}$

As a sharp contrast to this the Romanian Old Kingdom was organised in a highly centralised manner, where administrative and local autonomies existed only with the permission of central authorities and even then a strong central tutelage ensured that local decisions were largely in line with the opinion of the centre. At the same time the leader of the county level administration, the Prefect was the representative of the central government and the majority of the staff of the deconcentrated/decentralised institutions wasn't directly elected, but largely nominated by central authorities. The lack of administrative autonomy was also supplemented frequently by financial

2 The term (Romanian: Vechiul Regat) refers to the territory covered by the first independent Romanian state composed of the United Principalities of Moldova and Wallachia. 
constraints, where local communities had to contribute with significant financial resources to the budget of the central government (DUMITRU 2012c).

Given the above-mentioned circumstances there is no surprise that the vast majority of the local elite of the time, especially in the provinces, supported the establishment of a common, unified administrative system based on the decentralisation of central, governmental structures and local autonomy. However, given the heterogeneous structure of the new state, the fear of the emergence of centrifugal forces, added to this the centralised heritage of the Romanian Old Kingdom, it wasn't a surprise that the local elites, especially in Bucharest [Bucureşti] considering the volatile political circumstances of the time supported the establishment of a strong centralised state in the name of national consolidation.

The new system introduced by the administrative unification law of $1925^{3}$ was more of a compromise, rather than a comprehensive, thorough reform. Especially if we consider the unresolved issues posed by the increased territory of the state, the lack of socio-economic cohesion among historical provinces, not to mention the existing dysfunctions of the administrative-territorial organisation. Under these circumstances the administrative-territorial reorganisation of the state was inevitable. However, the question of administrative reform ignited the latent debate over centralist and regionalist views (DuMITRU 2012a, 2012b).

The majority of the liberals, mainly dominated by the National Liberal Party of the Old Romanian Kingdom - fearing the disintegration of the state in a regional construction - promoted the idea of centralism in the name of national consolidation, while the Conservatives pushed for a regionalist approach, taking use of the territorial diversity of Romania. The debate between centralism and regionalism was settled for a while with the parliamentary elections of 1928, when the conservative National Peasants' Party lead by Iuliu Maniu came into power. The new government quickly introduced structural reforms and with the implementation of the law for organising the local administration ( $3^{\text {rd }}$ August 1929) established a truly regional level by the creation of seven ministerial directories between central and local authorities mainly along the boundaries of the historical provinces (see Fig. 1, Fig. 4).

Although the reform established much larger territorial units, in reality we cannot speak about a true regional administrative level in the name of state decentralisation as envisioned by the government. Namely, although the aim of the reform was state decentralisation and the establishment of local autonomy, in reality the ministerial directories were administered by the representatives of the central government. Therefore the policy of state consolidation didn't disappear altogether. Besides central supervision this was also reflected by the names of the directorates, which by adopting the name of their capitals avoided the reference to the historical provinces (NISTOR 2000; Săgeată 2006; CovĂSNianu 2011; BuCur 2012; NACU 2012).

3 According to the administrative unification law of 1925 the Kingdom of Romania was organised into 71 județs, these incorporating 429 plăşi, 179 cities, 8,751 communes and 15,981 villages (Nistor 2000; Săgeată 2006; Covăsnianu 2011; KovÁcs 2011; Bucur 2012). 
The ministerial directories, mainly supported by the conservative government, were received with great controversy among the liberal opposition who interpreted the implementation of a regionalist approach as a threat to the stability of the newly born, fragile unitary state. Therefore in 1931, with the change of the government also changed the approach to state administration, where centralism was reinstated with the abolishment of the ministerial directories.

The last major administrative reform of the interwar period was implemented in 1938 with the introduction of the new Romanian Constitution, which once again established larger administrative-territorial units, so-called 'lands' (tinut) between the national and local (județ) level. The reform itself was imposed during the reign of Carol II, the King of Romania, and can be largely regarded as a move for consolidating the king's dictatorship, rather than one of state decentralisation. In addition, it was the first time in the history of modern Romania when through a regionalist approach centralisation and nonetheless territorial homogenisation was established at the national level. For example, one of the historical seats of Székelyland, that of Háromszék (Romanian: Trei Scaune) was incorporated into a new region, called Bucegi, having its centre in Bucharest (see Fig. 5) (SĂGEATĂ 2006, 2012b; Bucur 2012).

Figure 4: Romania in the interwar period: Administrative-territorial division 1929-1931

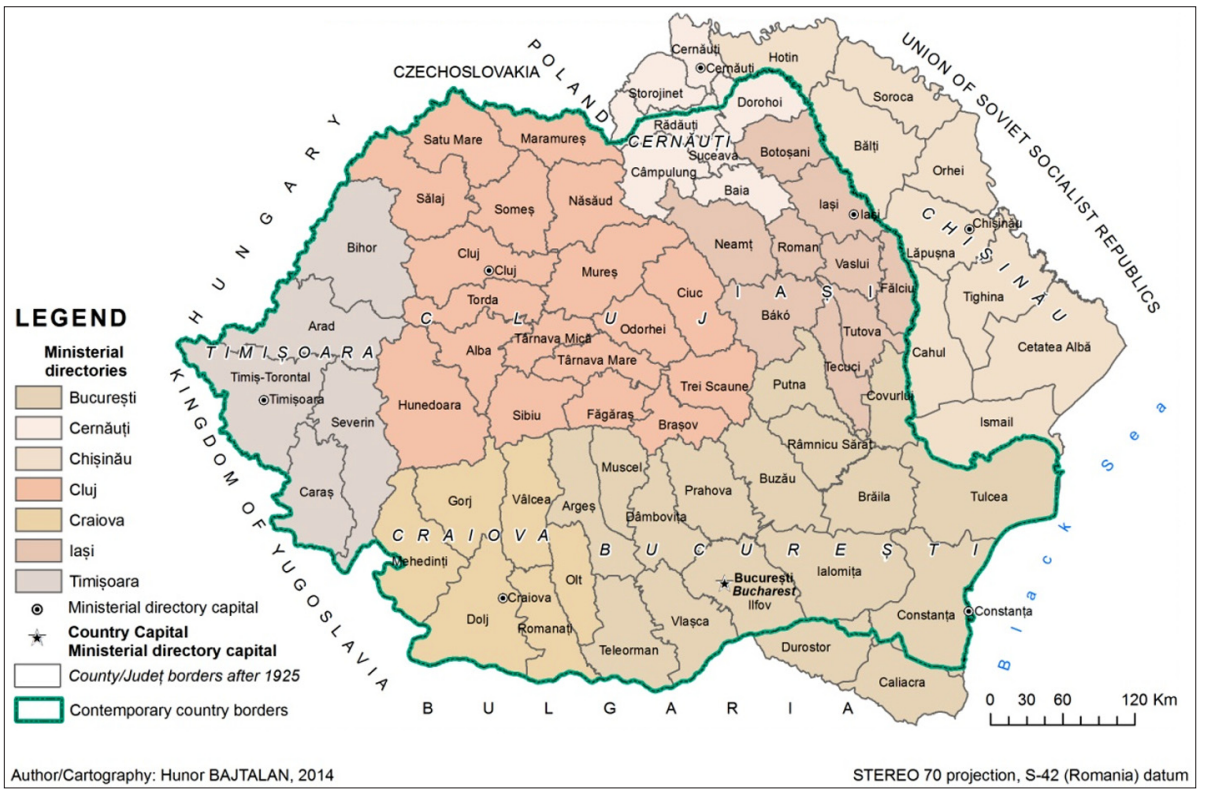

Sources: LAW FOR ORGANIZING LOCAL ADMINISTRATION 1929; PROIECTE DE ORGANIZARE ADMINISTRATIVĂ 1931; Moldoveanu 1934; Groza et al. 2008; Dumitru 2013c; ESRI HDR100 


\section{Figure 5: Romania at the eve of the Second World War: administrative-territorial division 1938-1940}

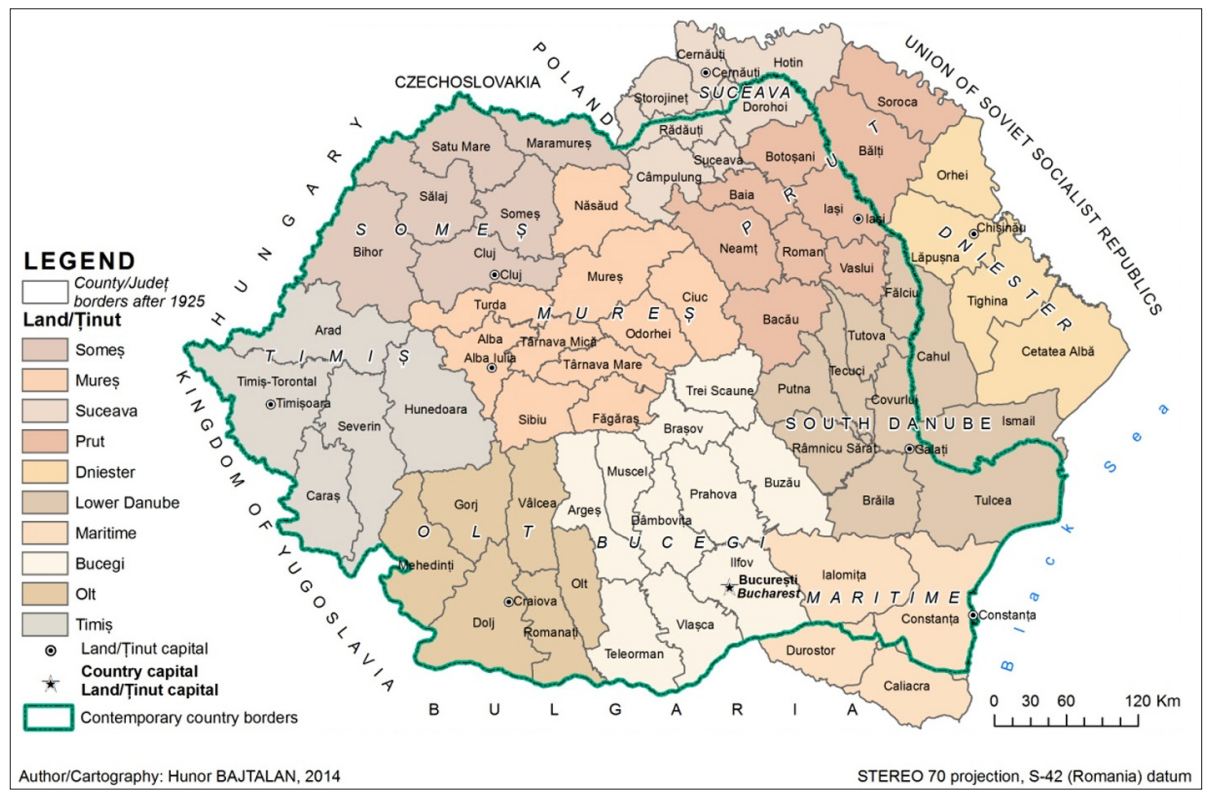

Sources: Law for administrative Reform 1938; Moldoveanu 1934; Conea 1938; Enciclopedia României Vol II 1938; GrozA et al. 2008; ESRI HDR100

The new lands didn't follow the cultural-historical or physical characteristics of the Romanian space. With the total ignorance of the historical provinces, they cut through natural regions and were regarded mainly as "geographic and economic entities, uniting the fraternal inhabitants of the new Romania after their real needs, considering their geographic location, the means of communication and resources they pose and the characteristics of their economic activity" (CĂLINESCU 1938, p. 4).

In the new system the județ lost their legal personality, transferring it to the lands, which on their turn were under strict central control through the presence of a governor nominated by central authorities. Therefore the new reform as noted by CoNEA (1938) was received with great controversy, the Romanian elite voicing their disagreement on much of the basic principles regarding the delimitation of the lands. Important personalities of the time, like Nicolae Iorga, Gheorghe Brătianu or Ion Conea strongly criticised the denial of the cultural-historical values, geographical characteristics of Romania.

The new lands, strongly connected to the dictatorship of King Carol II, were abolished with the abdication of the King mainly forced by the pro-German administration of Marshall Ion Antonescu. After the dissolution of the lands (tinut), the 
județ was restored throughout the Second World War as the basic unit of administration (Săgeată 2006; CovăSNiAnu 2011).

\subsection{Pseudo-regionalism 1952-1968: the instauration of the Soviet model}

The end of the Second World War brought the consolidation of Romania along the present-day country borders. Therefore Romania through the Paris Peace Treaties got back from Hungary Northern Transylvania, but had to give up the historical provinces of Bessarabia and Northern Bucovina to the Soviet Union. In addition, along with the rest of Central and Eastern Europe, Romania fell into the Soviet sphere, which resulted in the instauration of a Communist regime (BoIA 2012; DJuvara 2012; Hitchins 2013b).

Under the protective umbrella of the Soviet Union a new administrative system was introduced in the name of the State's role to fulfil local needs and requirements. The new system, largely based on the Soviet model (oblast, raion, commune), was enacted by the Law No 5 on the $6^{\text {th }}$ of September 1950, which established 28 regions (regiuni), subdivided into 144 districts (raioane) and 4,052 communes (comune) (see Fig. 6). The new regions didn't take into consideration the historical or geographical characteristics of Romania. Being largely drawn after 'complex socio-economic principles, they were interpreted as the only units that "directly supported the state's central organs in fulfilling state or party policies". Therefore, with the establishment of the Communist rule in Romania, the administrative-territorial organisation of the state entered strict political subordination (OroveAnU 1986, p. 211; SĂGEATÁ 2006).

According to the official ideology, the new administrative-territorial units had to break from the județ, which mainly were considered as legacies of the past. This was also reflected in the depersonalisation of the new regions through the adoption of the administrative seats' name as the regional name (see Fig. 6). The Soviet-Romanian friendship was even crowned with the naming of one region and regional seat after the great leader, Stalin (Braşov to Stalin City and Stalin region). As noted by SăGEATÃ (2011) the delimitation of the new administrative units was based on the idea of subordinating agricultural regions to larger urban centres by the creation of agroindustrial complexes to reinforce the proletariat's influence over the peasantry, which hardly wanted to accept the reform imposed by the Communist elite.

Near the political consequences, the new administrative units also resulted in serious economic difficulties and ample mutations in the traditional spatial structure of Romania. First of all the 58 județ through merging and dissolution were reduced to 28 regions. The settlement network was completely redrawn, the number of communes was reduced from 6,000 to 4,052 and the hierarchy of several cities was reorganised according to the new administrative system. Economically, the process resulted in the 
convergence of resources and investments in the new regional centres (SĂGEATĂ 2006; COVĂSNIANu 2011; Bucur 2012).

Figure 6: Administrative-territorial division 1950-1952

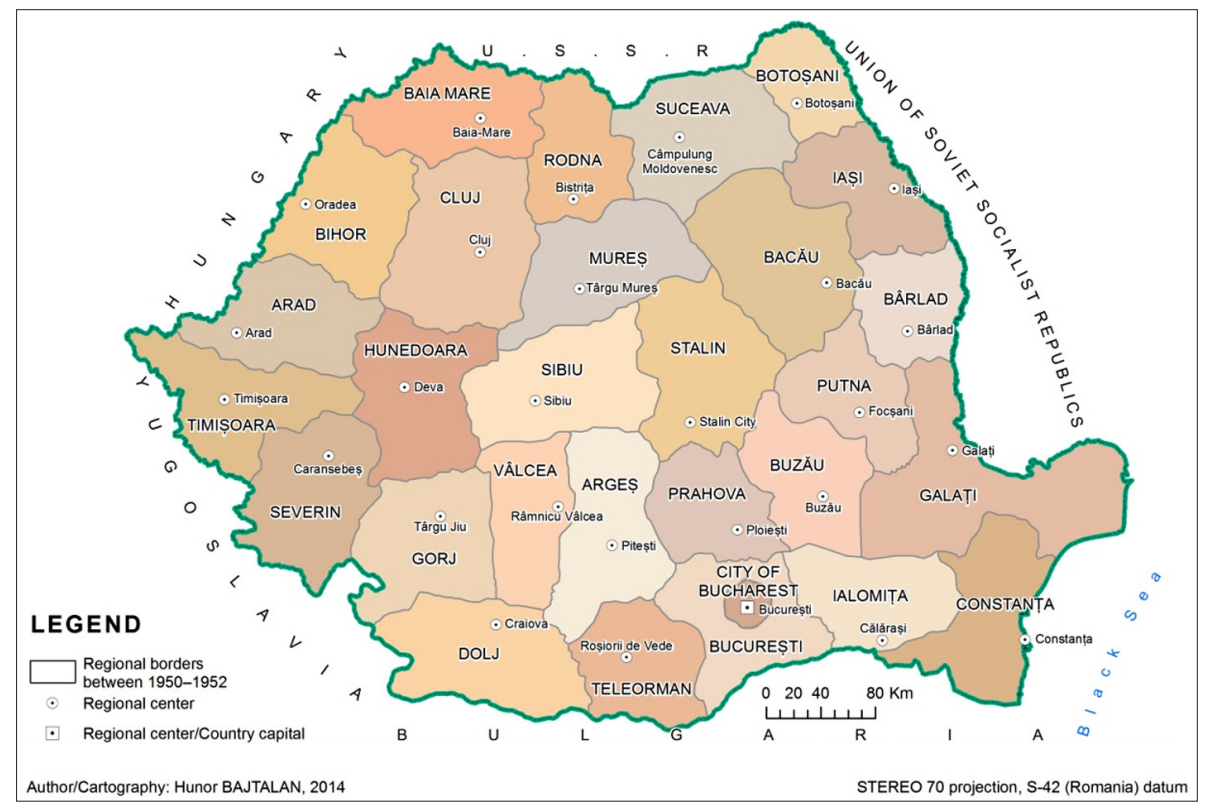

Sources: Law No. 5 for the creation of administrative-economic districts from 1950; GrozA et al. 2008; COVĂSNIANU 2011; ESRI HDR100

The new system, however, was very short-lived and proved to be a much too fragmented structure for the requirements of the time. Therefore, in 1952 with the introduction of the new Romanian Constitution, the number of the regions was reduced to 18. Twelve regions, namely Botoșani, Buzău, Dolj, Gorj, Ialomița, Mureș, Putna, Rodna, Severin, Sibiu, Teleorman and Vâlcea were dissolved, while two new regions appeared, i.e. Craiova and the Hungarian Autonomous Region, respectively. Subsequently, in 1956 another two regions were dissolved, namely Arad and Bârlad, thus resulting in a further reduction of the regions from 18 to 16 (see Fig. 7).

Above all, one of the most interesting aspects of the reform was the establishment of the Hungarian Autonomous Region in a country where national politics was dominated mainly by centralist views in the name of state consolidation and territorial homogenisation. The decision of the government wasn't a voluntary move towards historical reconciliation and the recognition of the minorities, but rather it can be interpreted as a Soviet-imposed policy. In fact, Stalin didn't want to accept the new Romanian Constitution - largely modelled after the Soviet one - until it granted 
administrative-territorial autonomy to the largest ethnic minority in Romania. For this even two Soviet experts, P. Arhipov and P. Tumanov were sent to the country and the implemented version of the autonomous province was largely based on their final proposal. In this context, however, as noted by KING (1973), Schöpflin (1979) and Botтoni (2008), Stalin's imposed Hungarian Autonomous Province and Soviet ethnic policy wasn't anything else than a showcase for home and abroad of the 'exemplary' treatment of the minority. In reality, it is obvious that in an era of totalitarianism we couldn't speak of neither self-determination, nor administrative-territorial autonomy (BotToni 2008).

However, Stalin's death in 1953 and the retreat of the Soviet troops from Romania in 1958 slowly changed the attitude of the government towards the policies imposed by the Soviet Union.

Figure 7: Administrative-territorial division 1956-1960

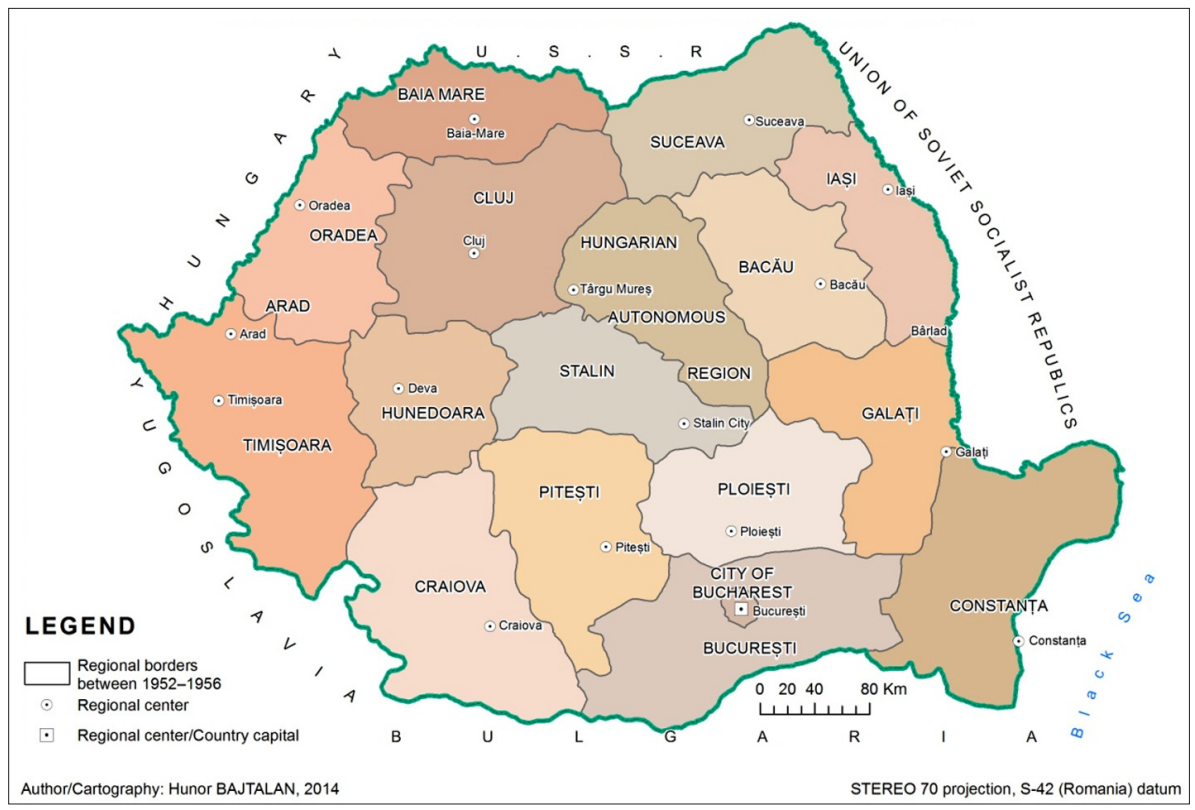

Sources: Decree No. 12 from 1956; Clement 1960; BăNĂRESCU et al. 1960; ESRI HDR 100

Under Gheorghe Gheorghiu-Dej traditional values gradually came back to the national level, first reflected in the change of the regional toponyms. Soviet-imported names, like Stalin and many other depersonalised names were changed, bringing back the old national values to the administrative map of Romania. As noted by SăGEATĂ (2006, 2011), this process largely coincided with a total political shift, from the outsideimposed Soviet Communism, mainly characterised by Stalinist uniformity through the 
rejection of the 'burgeois' past, to a nationalist Communist stage, where traditional values were rediscovered and the Soviet cultural model was rejected.

This process was also reflected in 1960 during the next major administrative reform, which reorganised the configuration of the 16 administrative regions. In the same time the cities of Bucharest and Constanța with their surroundings were raised to the regional level, the former for its role as the capital city, the latter for the development of the coastal areas of the Black Sea (see Fig. 8).

The biggest changes primarily referred to the internal configuration of the Hungarian Autonomous Region. With national-centralist views back at the centre of governmental policies, it was inevitable to dissolve a compact ethnic island in the heart of Romania. Thus, under the pretext of administrative reform, with the modification of regional boundaries, the government altered significantly the ethnic balances in the region. If in 1960 the population of the Hungarian Autonomous Region consisted of 76.9\% Hungarians (Székelys), with the reorganisation and the creation of the MureșHungarian Autonomous Region, this number fell to $61.1 \%$. However, the political shift wasn't just reflected at administrative level. The unexpected disappearance of several Stalin monuments, as well as the change of regional toponyms tried to symbolise the return of traditional policies, historical values to the national level (SĂGEATÁ 2006; Bottoni 2008; COVĂSNianu 2011; Bucur 2012).

Figure 8: Administrative-territorial division 1960-1968

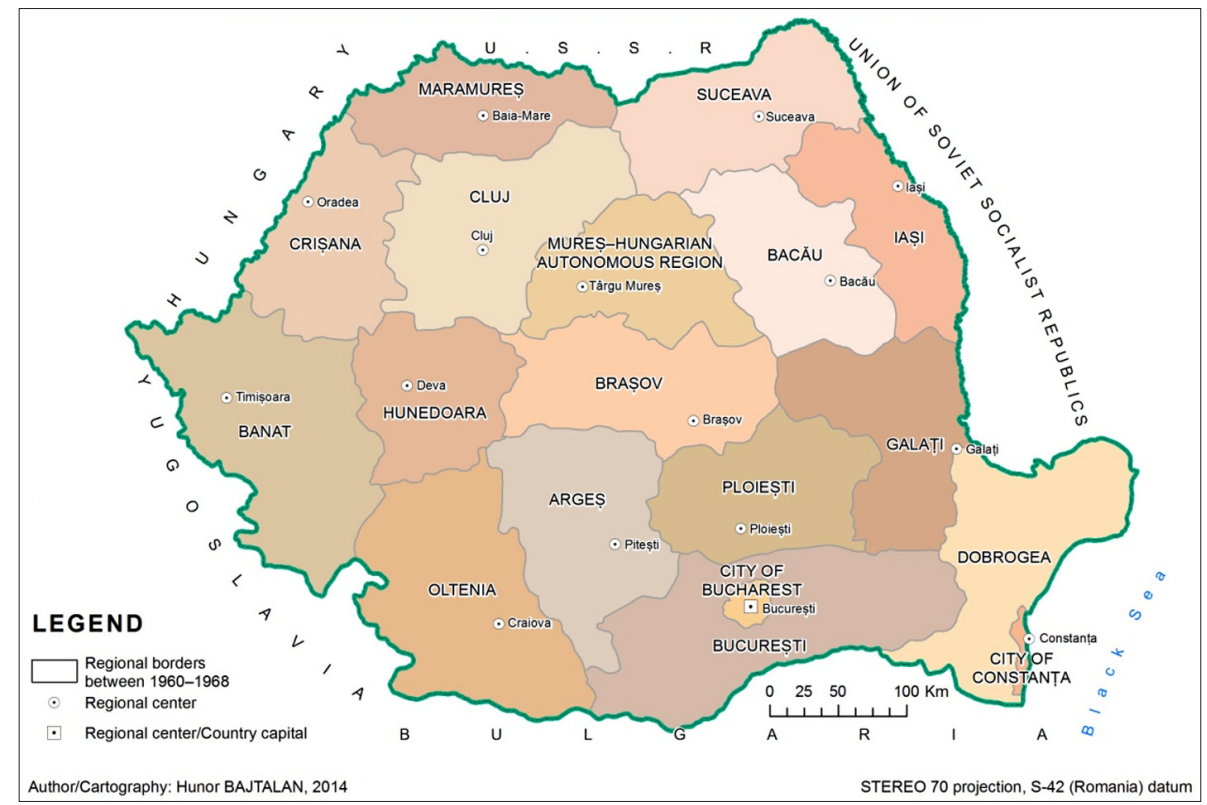

Sources: Law No. 3 from 1960; Atlas Mira 1967; ESRI HDR100 


\subsection{The return of centralism: administrative-territorial organisation 1968-1989}

The detachment process from the Soviet Union culminated during the dictatorship of Nicolae Ceaușescu - the key moment of this being the condemnation of the Soviet invasion of Prague [Praha] in 1968 by the newly elected president himself (DELETANT 2006). However, such a political move in foreign policy of Romania involved not only the consolidation of internal power relations around the Ceaușescu regime, but also the stabilisation and 'pacification' of the hinterland of the country (NovÁK 2005). In this context the administrative-territorial reorganisation of the state was imminent. The first concrete steps in this direction were taken right after the election of Nicolae Ceauşescu as the General Secretary of the Romanian Workers' Party (later called Romanian Communist Party). During the $9^{\text {th }}$ Congress of the Romanian Workers' Party the new leadership by laying down the founding ideas for the development of the country, drew the line for the beginning of a new era both politically and ideologically. Among others the Congress declared that with the elimination of exploiting social classes and the dissolution of class struggle in the society Socialism triumphed in Romania. It was also decided that the administrative reorganisation of the state became imminent, as well as the systematisation of the settlement network and the optimisation of the centrally planned economy. During the summer of 1967, on the $14^{\text {th }}$ of July, the politburo elaborated the first drafts for the reorganisation of the state, which brought back the traditional administrative unit, the județ. The basic principle of the reorganisation was that in contrast to the regions created between 1950 and 1960 based mainly on the concept of economic homogeneity, the județ should be founded on an economic diversity in the name of complementarity and functionality (NovÁK 2005; SăGEATÃ 2011).

Geographically speaking the new județ constituted a total detachment from the Soviet-imposed administrative organisation of the 1950s and the 1960s. The territorial disparity between the new județ was much smaller than among the județ of the interwar or the regions of the Soviet period. The settlement structure was redesigned, mainly promoting the development of those cities or urban areas that had a geographically central location in the new județ. Therefore in some cases the administrative function was given to smaller urban centres, largely based on geographical principles, rather than according to their level of development or urbanisation. In this respect a lot of moderately urbanised settlements got an impetus for development at the expense of the slow degradation of traditional urban centres (S̆̈GEATĂ 2011).

Thus according to Law No. 2 from 1968, the territory of Romania was organised into 39 administrative-territorial units, called județs, 47 municipalities and 189 cities, largely modelled after the French departmental system (see Fig. 9) (SĂGEATĂ 2006; COVĂSNIANu 2011; BuCur 2012). 
Figure 9: Administrative-territorial division 1968-1981

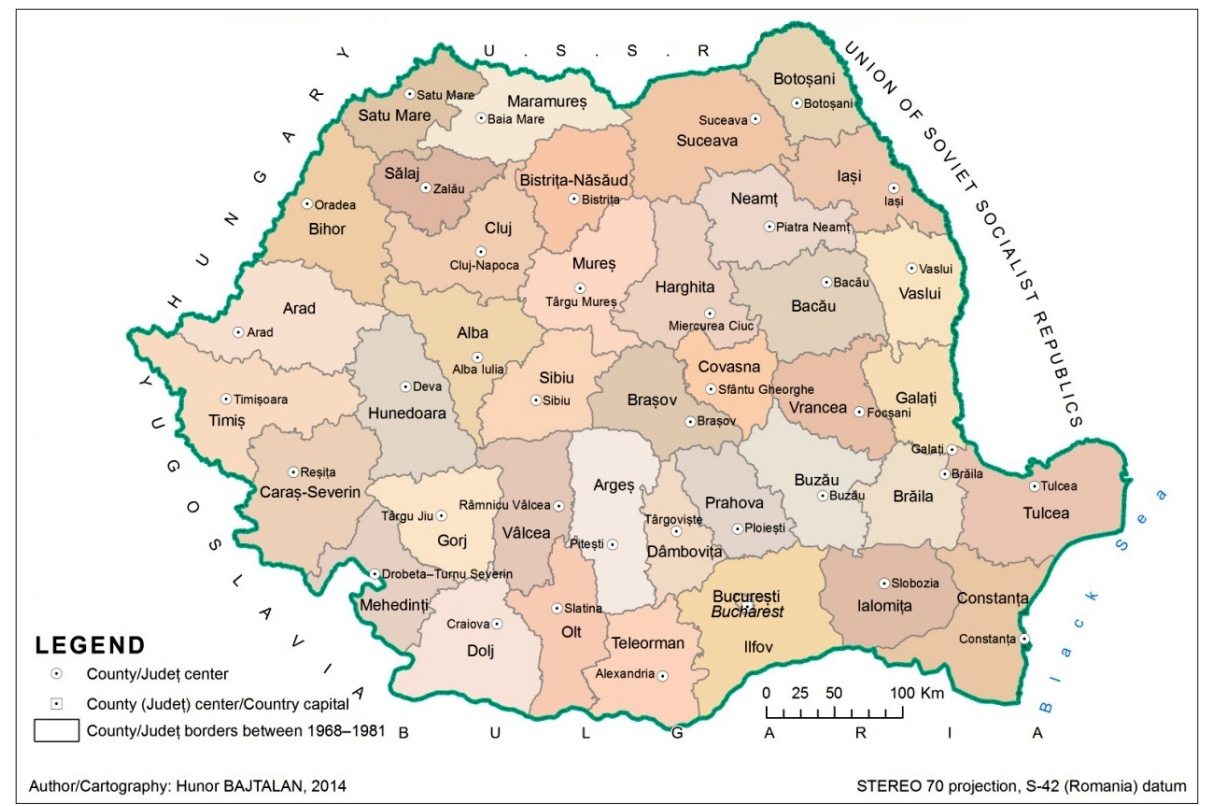

Sources: Law No. 2 on administrative-territorial organisation of S.R. Romania from 1968; Cucu et al. 1984; GrozA et al. 2008; ESRI HDR100

The county/județ system introduced in 1968 proved to be an adequate, functional solution for the administrative-territorial organisation of Romania. The best proof of this being the relative stability of the system, which with minor modifications survived the transition from Communism to democracy, from a centrally planned economy to the market-oriented spatial structure of the new Romania. The large Ilfov județ as the polarising area for Bucharest proved to be unviable. Therefore, in 1981, together with Ialomița, it was reorganised into four smaller județ, i.e. Giurgiu, Ialomița, Călărași, Ilfov and Bucharest. Initially, i.e. 1981-1996, Ilfov was subordinated to Bucharest as an Agricultural District, later in 1996 gaining județ status (see Fig. 10).

\subsection{Towards a regional approach (1989-2007)}

By the revolutions of 1989 the Communist regimes in Central and Eastern Europe collapsed and the countries of Central and Southeast Europe were opened up to the forces of the global economy (TATUR 2004). On a spatial level, under the appearance of the free market's centripetal and centrifugal forces, this meant the reorganisation of the centrally planned spatial structure of Romania. Throughout the 1990s territorial disparities have risen consistently, major urban agglomerations being the big winners 
of the transition at the expense of the countryside (STEINHERR \& Gros 1995; RAmbøLL 1996; Lefter \& Constantin 2009; Sandu 2011; BenedeK \& Kurkó 2010a, 2010b).

Under these circumstances there is no surprise that the question of administrativeterritorial reorganisation quickly came back to the political agenda, although the thematisation of the issue took very diverging paths of development throughout the 1990s. First of all, with Romania's transitional momentum, appeared the very first seeds of bottom-up oriented civic initiatives, which were mainly in line with the general movements to eradicate the last remnants of Communism. To these can be counted also the movement initiated by the League for the Revival of the Abusively Abolished Counties [Liga Județelor Abuziv Desființate], which promoted the restoration of the historical interwar county structure of Romania, although without gaining any serious political support (Iordan \& AleXANDrescu 1996; Iordan 2003; SĂGEATă 2013).

During the late 1990s the debate on the necessity of administrative-territorial reform took a new, very controversial approach through the appearance of a pamphlet written by Sabin GHERMAN - a journalist from Cluj-Napoca - who openly plead in favour of administrative-territorial autonomy for Transylvania. His proposal deliberately entitled 'I have had enough of Romania' with its provocative language, generated a very heated public debate mainly receiving highly emotional and at least overreacted responses. The public's vehement refusal wasn't a surprise either, because GHERMAN's vision of a Romania of autonomous regions, based on the principles of subsidiarity and fiscal autonomy, stood in a sharp contrast to the unitary conscience and centralist tradition of the Romanian nation state (GHERman 1998; SzöCs 2000; SăGEATĂ 2006; Boia 2001; Hitchins 2013; BaJTALAN 2013).

Parallel to these, after 1989 a third theme - mainly connected to the ethnical heterogeneity of the country - began to emerge, and from time to time through the strengthening self-determination movements of the Hungarian community, especially in the Székely Region reinstated itself as one of the main catalysing forces behind the debate on the administrative-territorial reorganisation of the state (BAKK 2004; BognÁR 2006). This is hardly surprising if we take into consideration that 1,237,746 ethnic Hungarians live in Romania, mainly in Transylvania (18.1\% of the population), representing $6.5 \%$ of the total population of the country $(19,042,936)$ according to the 2011 National Census. In two counties, Harghita/Hargita (84.8\%) and Covasna/ Kovászna (73.6\%), they have absolute majority, while in Mureș/Maros (37.8\%) they are not far from the $40 \%$ threshold of the county population (KISS \& BARNA 2012). ${ }^{4}$

However, the most influential catalysing force behind the construction of the regional level was connected to the accession process to the European Union. With the conditionality of adopting the acquis communautaire, the European Union largely motivated and legitimised the adoption of vital reform and the overall modernisation of the state. This was also true in the field of spatial policy, where the EU through the PHARE programme provided technical assistance for the preparation of a regional

$4 \quad$ For a more detailed insight into the question of Székelyland in the context of Romanian administrative-territorial reform initiatives see the work of BENEDEK \& BAJTALAN (2015). 
policy in Romania. This in the first phase materialised in a series of analyses and studies on territorial disparities in Romania (RAmbøll 1996; IANoș \& PASCARIU 2012).

The conclusions of these studies led to the drafting up of a concrete set of principles, instruments and policy proposals for the establishment of a regional development policy in Romania. This materialised in "The Green Paper. Regional Development Policy in Romania" elaborated by a group of international experts, mainly RAMBøLL, an inter-ministerial task force and several representatives of the academic and civic community. The paper based on the preliminary studies conducted in the field of regional policy in Romania, provided a synthesis about existing territorial disparities and through the presentation of several European examples for regional policy proposed a set of instruments, policies, an action plan and an implementation model for the creation of a regional development policy in Romania. At the same time the paper also indicated that "from the perspective of development it would be much more effective if the country would be divided into a smaller number of development regions, based on the grouping of counties (județ) according to their similar level of development." Thus a structure of eight development regions was proposed between the national and county level to facilitate the implementation of regional policies (see Fig. 10). The development regions were delimitated according to a set of complex

\section{Figure 10: Development regions in Romania since 1998}

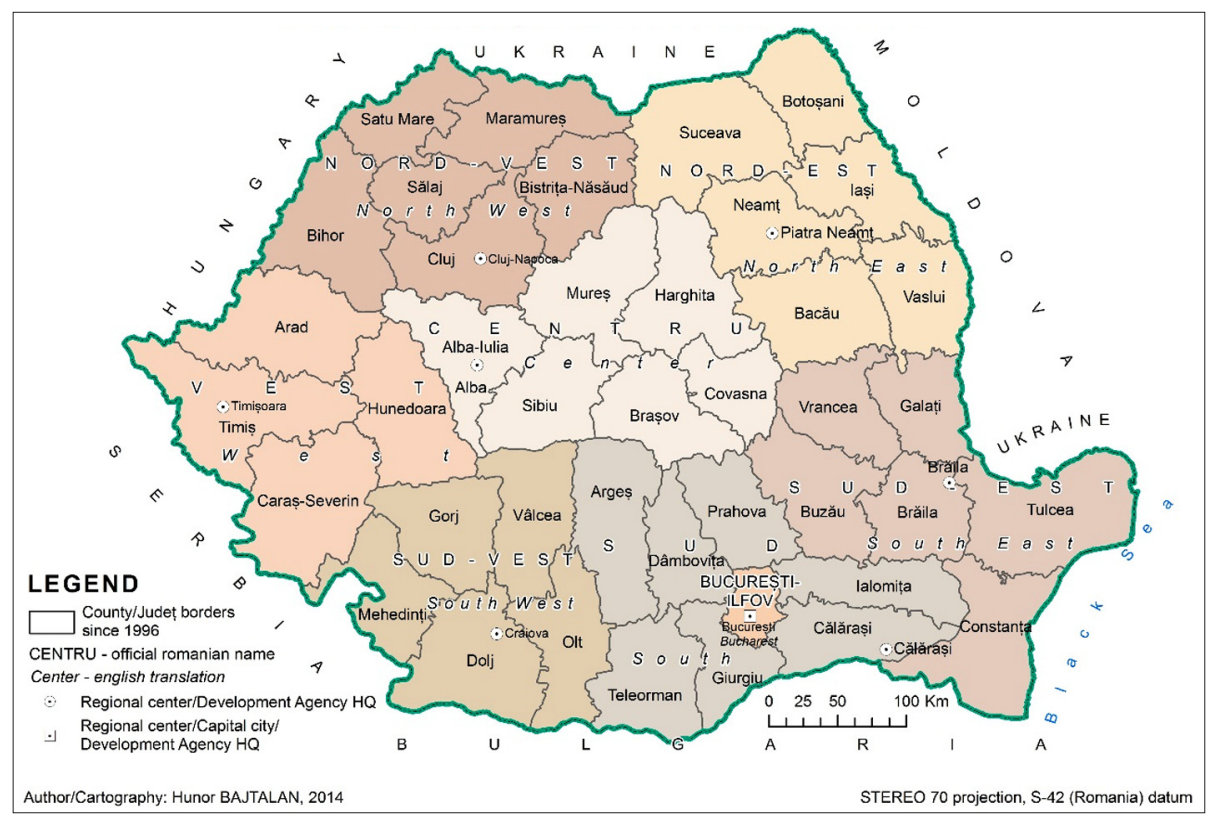

Sources: Green Paper 1997; Law No. 151 on regional development in Romania from 1998; ESRI HDR100 
criteria, i.e. surface and population size, geographical aspects, functional relationships, connectivity and complementarity in economic resources. Although the international conference, which presented the Green Paper recommended the decentralisation of the state along with the creation of a regional policy in Romania, in reality the adopted measures can be regarded as ad hoc solutions to meet the accession requirements imposed by the European Union (IAnOş \& PASCARIU 2012).

Therefore, the main proposals of the report, without any significant modifications, were accepted and the legal framework was created with the adoption of the law for regional development in Romania in 1998. Institutionally speaking the new development regions represent more of a compromise, an ambiguous solution between centralism and regionalism. They are not legal entities and their functions are mainly limited to the establishment, implementation and evaluation of regional development policies. The development regions are administered by the National Council for Regional Development, the coordinating bodies being the Regional Development Agencies and the Regional Development Councils. Therefore, the development regions have very limited decision-making capabilities and are largely subordinated to the central government. They also pose a democratic deficit, because they do not enjoy any form of legitimacy through local or regional elections (BENEDEK \& JoRDAN 2007; BENEDEK 2009).

In this context the implementation of the Romanian regional policy as well as the establishment of the development regions can be interpreted as a top-down oriented process of regionalisation rather than a bottom-up oriented process of regionalism. As noted by BENEDEK (2009) and also elaborated in this paper, given the strong centralist tradition of the Romanian state, this is hardly surprising.

\subsection{Regionalisation after EU accession: a superficial, yet pragmatic approach towards regions}

After Romania's accession to the EU, the question of reorganising the current state structure quickly came back to the political agenda, mainly brought up initially in 2011 by state president Traian Băsescu and the then ruling Democratic Liberal Party (DLP). This time, however, the necessity to create administrative-territorial regions was linked to more pragmatic considerations (BAJTALAN 2014). First of all the 20072008 Global Financial Crisis in 2009 began to hit hard the economy of Romania, which compared to 2008 in terms of GDP began to contract by more than 7\% (STOICIU 2012). As a result harsh austerity measures were introduced and the public sector had to be largely curtailed. According to the president himself the 'Fat Man' as he described the state of public administration, had to be reformed (VANGHELE 2010). Therefore words like efficiency, economies of scale, as well as the notion of decentralisation and deconcentration slowly began to spread in public and political discourses. At the same 
time there was also the headache posed by the slow absorption rate of EU structural funds, which at the time of austerity could have brought the deeply needed capital and investments into the struggling economy.

Under these circumstances, a thorough administrative-territorial reform was proposed, with the transformation of the eight already existing development regions (see Fig. 10) into administrative-territorial entities. Unfortunately, however, the whole process in the absence of a clear proposal backed by comprehensive feasibility studies, not to speak about public consultations, remained only on a declarative, political statement level. It is also unfortunate that the initial principles of the reform process, namely subsidiarity and decentralisation were largely neglected, and the whole societal discourse, mainly due to public support, shifted to more populist, superficial aspects. At a certain point a form vs. functionality paradox began to emerge, where people were more interested in the future 'borders' and 'capitals', in the overall spatial characteristics of the new administrative-territorial units and less in the more serious, pragmatic aspects of the reform process, like what kind of rights will be conferred to these new units, or will they have legislative authority as well regionally elected bodies and representatives, etc. Thoughtlessness and superficiality was present also in the relationship of the ruling DLP with the coalition partner, the Democratic Alliance of Hungarians in Romania (DAHR). The proposal forwarded by the DLP rejected from the very beginning the bottom-up oriented movements of self-determination of the Hungarian ethnic community in Transylvania, specifically in Székelyland, which stood in a sharp contrast to the political programme of the DAHR. In this respect it was obvious that without the support of the DAHR any initiative towards an administrativeterritorial reorganisation was condemned to failure (BAJTALAN, in print).

The necessity to establish a functional and efficient administrative system was once again brought back to the political agenda as one of the key themes of the 2012 legislative elections, from which - mainly as a result of the post-crisis discontent wave - the two thirds majority winning Social Liberal Union (SLU) didn't constitute an exception. After the formation of the new government, the ruling SLU under the three thematic pillars of 'Development, Decentralisation, Regionalisation' initiated a thorough process of administrative-territorial reform. Officially, the reform process started from the consideration that "in the following period Romania has to overcome a serious economic gap, that it faces towards Europe, by bringing public services and decisions closer to the ordinary citizen - according to the European principle of subsidiarity - and by using existing resources in a more efficient way: local resources, governmental funds and European possibilities" (Government of Romania, Statement of the Ministry of Regional Development and Public Administration 2013).

In the background, however, it was obvious that the reform process is motivated once again by the existence of a highly centralised, bureaucratic and inefficient public administration, which, although largely curtailed during the financial crisis, was right due to a lack of structural reforms largely responsible for the low absorption rate of EU funds. The risk of losing the majority of the budget allocated to Romania during the 
2007-2013 financial period of the EU posed a serious concern for the new government, which in times of economic hardship deeply needed fresh capital to shake up the struggling Romanian economy. Therefore there is no surprise that the new government soon became obsessed with the modernisation of public administration and the question of EU funds (ECONOMIST 2012; BAJTALAN, in print).

From the very beginning a very controversial reform process began to emerge, especially if we consider that Romania was in the middle of a negotiation and accreditation process for the next financial period (2014-2020) of the EU and the coalition wanted to push through the process in one year, during 2013. In this respect one of the most intriguing aspects was that both the Permanent Representation of Romania to the European Union as well as the National Institute of Statistics (INS) informed the Commission in February 2013 that in the framework of the NUTS2013 revision process, Romania will not propose any changes to the current NUTS system (NUTS-2010) (ŠEMETA 2014; MinĂILESCU 2014). Taking into consideration the strict regulations of the EU regarding the modification or amendments to existing NUTS classifications (Reg. No 1059/2003 and No 1046/2012), it became obvious that the government, although on the surface open to debate new proposals, in the background largely supported the proposal of the former DLP government. Under these circumstances the government tended to preserve the current status quo by transforming the current development regions into administrative-territorial units (see Fig. 10), mainly because this scenario had the lowest consequences in terms of costs and conflict risks.

Although the government tried to back up the reform process by a series of public consultations organised all over Romania, yet in the absence of a clear proposal these were more like campaigns to promote and legitimise the reform process itself than comprehensive approaches to engage with bottom-up oriented initiatives. Unfortunately, the technical body, the Consultative Council for Regionalisation (CONREG) that was entrusted with the elaboration of a concrete policy proposal, proved to be nothing else than a tool in the hand of the government to scientifically underpin already decided proposals (CONREg 2013a, 2013b; CsÁK 2013; SzABó 2014). Given the political frictions and internal tensions of the ruling coalition, in addition the superficiality and hasty preparation of the reform process, not to mention the lack of public support for a constitutional revision that was necessary, there is no surprise that the initiative of the coalition ended up in failure.

As a movement of last resort the coalition tried to materialise some aspects of the reform proposal through a decentralisation draft bill, according to which several central governmental functions would have been decentralised, better to say deconcentrated to county level institutions, however without transferring their funding from central authorities. The initiative can be regarded as a compromise between the centre and local, county-level ruling elites who feared that the government-initiated regionalisation process could lead to diminishing their rights and influence. However, the hastily adopted superficial bill by governmental responsibility was immediately 
attacked by the DLP at the Constitutional Court. The Constitutional Court decided unanimously, backed by a 106-page motivation that the government's decentralisation bill clearly violated the Constitution mainly around the principle of local autonomy and the constitutional regime of property (Romanian Government 2013; Constitutional Court of Romania 2014; Benedek \& Bajtalan 2015).

\section{Conclusions}

The aim of this paper was to draw up a preliminary analysis about the state of the meso-level administrative division in Romania from the establishment of the first seeds of administrative-territorial organisation of the Romanian nation state until present-day Romania. The fundamental direction of inquiry was a holistic, historicalgeographic one, chosen not by mistake, because recent discourses towards region building in Romania largely neglected the heritage of the past as well as previous, in some cases functional models of state organisation. As a result of this analysis we can conclude that considering its function as well as its relationship towards the ruling elite the meso-level administration in Romania went through a development in three distinct phases:

I. The phase of national consolidation is characteristic to the era of Romanian nation-building present from the establishment of the first Romanian nation state throughout the interwar period until the fall of the country into the Soviet sphere. In this period, although it was recognised that local, bottom-up oriented initiatives as well as the establishment of local autonomy and the principles of decentralisation were indispensable for the harmonious development of the state, it was a widespread view among the ruling elite that freeing up local energies could put an end to the hardly achieved unity. This prevented any serious approach towards the establishment of a regional administrative level. This approach was especially reinforced after the First World War, when by gaining a significant amount of territory and population Romania had become a much more heterogeneous country with significant socio-economic disparities and a diversity of minorities. Administrative regions, even if they existed, were interpreted more like agents of the centre in the name of national consolidation and territorial control.

II. With the appearance of the Communist regime also appeared a new ruling elite that had to consolidate its power in the provinces. Therefore the phase of national consolidation was substituted by a phase of power consolidation, where administrative regions were conceived as a framework of consolidating the power of the new ruling elite in the provinces. Any connection to the interwar county structure was rejected, boundaries were redrawn and toponyms were 
changed. As a result Soviet-type pseudo-regions were established, mainly with the role of executing state and party policies on the local level.

III. After the revolution of 1989, socio-economic transition has shaken the spatial structure of Romania. The centrally planned economy collapsed, and as a result systematic change abolished the central structures of wealth redistribution and regional equalisation. In this chaos it became obvious that the current administrative system cannot meet the challenges of the $21^{\text {st }}$ century, especially if we consider that the current county structure is a heritage of a very different past, originating in 1968. Therefore, with EU accession ahead and facing the necessity to establish a EU-conform regional policy as well as to adopt the acquis communautaire a new phase began to emerge. This came as a result of EU conditionality, but also as an internal recognition of the necessity to modernise state administration (Hughes, SAsse \& Gordon 2005).

Considering what was presented above we can conclude that although there were historical precedents when the regional administrative level began to establish itself, in reality it evolved around the Napoleonic tradition of strong centralism. Under these circumstances even if administrative regions were established, they had very limited self-governing competencies and were largely subordinated to central authorities. This path of development of the administrative meso-level cannot be excluded from current political and academic discourses, because this historical heritage influences even today the characteristics of state administration. It is for sure that administrative regionalisation will also be part of future considerations, but - given the strong centralist traditions of Romania - it is also certain that a strong inclination exists towards preserving the existing situation, because this is the one that presents the lowest costs and conflict risks (BENEDEK \& BAJTALAN 2015).

\section{References}

Allen J., Massey D., Cochrane A. (1998), Rethinking the region. London, Routledge.

Andree A., Scobel A. (1905), Andrees Allgemeiner Handatlas. Bielefeld - Leipzig, Velhagen und Klasing. Retrieved from David Rumsey's Map Collection, $<$ http://www.davidrumsey. $\mathrm{com} />$

Bajtalan H. (2013), A regionalizázió folyamata Romániában: 1859-2013. In: Erdélyi Társadalom, 9, 2, pp. 67-84.

BAJTALAN H. (in print), Regionalisation in Romania: recent discourses, projects and perspectives. Cluj-Napoca, Studia Universitatis Babeș-Bolyai Geographia.

BAKK M. (2004), Az autonómia-tervek két szakasza Erdélyben 1989 után. In: Magyar Kisebbség, 9, 1-2, pp. 39-60. <http://www.jakabffy.ro/magyarkisebbseg/pdf/2004_1-2_03_bakk.pdf $>$ (27.08.2014) 
Barraclough G., Stone N. (1992), The Times Atlasz Világtörténelem. Budapest, Akadémiai Kiadó.

Bartholomew J.G. (1922), Times survey atlas of the World. London, John Bartholomew and Son. Retrieved from David Rumsey's Map Collection, $<\mathrm{http}$ ://www.davidrumsey.com/>

BenedeK J. (2004), Amenajarea teritoriului și dezvoltarea regională. Cluj-Napoca, Presa Universitară Clujeană.

BenedeK J. (2009), The Emergence of New Regions in Transition Romania. In: Scott J. (ed.) De-coding New Regionalism: Shifting Socio-political Contexts in Central Europe and Latin America, pp. 233-246. Cornwall, Ashgate.

Benedek J., Bajtalan H. (2015), Recent regionalisation discourses and projects in Romania with special focus on the Székelyland. In: Transylvanian Review of Administrative Sciences, 44, pp. 23-41.

BenEDEK J., JoRDAN P. (2007), Administrative Dezentralisierung, Regionalisierung und Regionalismus in den Transformationsländern am Beispiel Rumäniens. In: Mitteilungen der Österreichischen Geographischen Gesellschaft, 149, pp. 81-108.

BENEDEK J., KuRKó I. (2010a), Evoluţia şi caracteristicile disparităţilor teritoriale din România. In: BenedeK J., BAKK M. (ed.), Politica regională în România, pp. 77-120. Iaşi, Editura Polirom.

Benedek J., Kurkó I. (2010b), The Evolution of Regional Economic Disparities in Romania. In: Transylvanian Review, 19, S4, pp. 143-158.

Blaga L. (1969), Trilogia Culturii. București, Editura pentru Literatură Universală.

Bognár Z. (2006), Romániai magyar autonómiakoncepciók. Az 1989 és 2006 között kidolgozott törvénytervezetek. In: Bognár Z., Egry G., Fejtö F., Ludassy M., Salat L. (eds.), Autonómia, liberalizmus, szociáldemokrácia. Budapest, Európai Összehasonlító Kisebbségkutatások Közalapítvány. <http://adatbank.transindex.ro/belso.php?alk=48 $\& \mathrm{k}=5>(27.08 .2014)$

Bora L. (2001), History and Myth in Romanian Consciousness. Budapest, Central European University Press.

BoIA L. (2012), România țară de frontieră a Europei. București, Humanitas.

Botтoni S. (2008), Sztálin a székelyeknél. A Magyar Autonóm Tartomány története (19521960). Csíkszereda, Pro-Print Kiadó.

Bucur C. (2012), Organizarea administrativ-teritorială a României între tradiție istorică, dictat politic, sincronism european, decizie administrativă și analiză științifică. In: Urbanismul serie nouă, 11 , pp. 50-56.

Călinescu A. (1938), Spiritul noului regim administrativ. In: Gusti D., Orghidan C., Vulcănescu M., Leonte V., Buzatu Gh. (eds.) (1938), Enciclopedia României. Vol. II, pp. 3-5. București, Imprimeria Națională.

Charta României Meridionale [1864], digitized by Bartos-elekes Zs., ImeCs Z., Magyari-SÁsKa Zs., TímÁR G. (2014). Retrieved from <http://www.charta1864.ro/>

Clement V., Dunărescu-Ionescu I., Cergău L. (1959), Republica Populară Română, harta

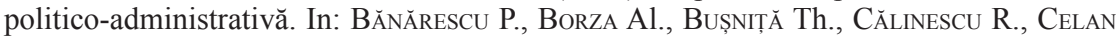
M., Conea I., Coteț P., Demidovici A. I., Diaconu D., Dumitrescu S., Dumitrescu V., Florea N., Fridland V. M., Gâstescu P., Herbst C., Iancu M., LăZărescu D., Martiniuc C., Morariu T., Oleinikov I.N., Oncescu N., Panait I., Pașcovschi S., Paucă A., Pop Em., Pușcaru-Soroceanu E., Rădulescu I., Savu Al., Sârcu I., Stoenescu Șt.M., Ujvári I. (eds.), Monografia Geografică a R.P.R., Vol I. Geografia Fizică. Anexa I. București, 
Academia R.P.R. Institutul de Geologie și Geografie - Academia de Științe a U.R.S.S. Institutul de Geografie - Editura Academiei R.P.R.

CONEA I. [1938] (2012), Sugestii și indicații geo-istorice pentru numirea și determinarea marilor unități administrative ale României. In: Urbanismul serie nouă, 11, pp. 10-20.

Constitutional Court of Romania, Decision No. 1 from 10 January 2014. <http://www.ccr.ro/ files/products/Decizia_1-2014.pdf> (15.10.2014)

Consultative Council for Regionalisation (Conreg) (ed.) (2013a), Fundamentele Procesului Actual de Regionalizare în România. <http:/cursdeguvernare.ro/wp-content/uploads/ 2013/05/Raport-CONREG-I-final.pdf> (15.10.2014)

Consultative Council for Regionalisation (Conreg) (ed.) (2013b), Disparități și fluxuri în fundamentarea social-economică a regionalizării administrative a României. Consiliul Consultativ pentru Regionalizare. <http://www.regionalizare.mdrap.ro> (13.10.2014)

CovĂSNIANu A. (2011), Regiunile de dezvoltare în România europeană. Între deziderat politic și realitate teritorială. Doctoral dissertation. Iași, Alexandru Ioan Cuza University.

Cś́k L. (2013), Bukfencretorika, Transindex, 19 May 2013, <http://itthon.transindex.ro/?cikk $=20331>(27.08 .2014)$

Cucu V., Iordan I., Dumitru A. (1984), Geografia României, Vol III. Geografia umană și economică. București, Editura Academiai R.S.R.

CvisIĆ J. [1918] (2012), La Peninsola Balcanica. Trieste, Università degli Studi di Trieste. $<$ http:// www2.units.it/labgeo/balkan.rtf> (15.06.2014)

Cziprián-KovÁcs L., Kozma Cs. (eds.) (2003), Erdély közigazgatás-története. Sepsiszentgyörgy, 'Pro Scientia Administratica' Tudományos Társaság.

Deletant D. (2006), Romania under communist rule. Bucharest, Civic Academy Foundation.

Duuvara N. (2012), O scurtă istorie a românilor povestită celor tineri. București, Humanitas.

Dobre A.M. (2010), Romania: from historical regions to local decentralisation via the unitary state. In: Hendriks F., Lidström A., Loughlin J. (eds.), The Oxford Handbook of Local and Regional Democracy in Europe, pp. 685-713. New York, Oxford University Press.

Dumitru B. (2012a), Centralism or Autonomy? The Debate Regarding the Administrative Organization in Romania between 1918-1925. In: Studia UBB Europaea, 57, 2, pp. 83-107.

Dumitru B. (2012b), Federalism and Regionalism in Romanian Political Thinking in the Interwar Period. In: Studia UBB Europaea, 57, 1, pp. 15-36.

Dumitru B. (2012c), Modele privind organizarea administrativă a României în perioada interbelică. O perspectivă comparată. Doctoral dissertation. Cluj-Napoca, Babeș-Bolyai University, Faculty of European Studies.

ECONOMIST (ed.) (2012), EU funds absorption in Romania: A funding obsession, The Economist - Eastern approaches, 5 June 2012, <http://www.economist.com/blogs/eastern approaches/2012/06/eu-funds-absorption-romania> (27.08.2014)

Editura Institutului Cartografic 'UNIREA' (ed.) (1922), România. Brașov. Retrieved from the map collection of the Cholnoky Jenö Geographic Society <http://hagyatek.cholnoky. $\mathrm{ro} />$

EGYED Á. (2006), A székelyek rövid története a megtelepedéstől 1918-ig. Csíkszereda, PallasAkadémia Könyvkiadó.

ELEKES T. (2011), Székelyföld közigazgatás-földrajzi változásai a 13. századtól napjainkig. In: Földrajzi Közlemények, 135, 4, pp. 415-429.

ESRI Romania (ed.), Harta Digitală a României - Scara 1:100.000 (HDR100). Retrieved from $<$ http://www.arcgis.ro/Item.aspx?item=207> 
European Commission (ed.) (2012), Commission Regulation No. 1046/2012 of November 2012 on implementing Regulation (EC) No. 1059/2003 of the European Parliament and of the Council on the establishment of a common classification of territorial units for statistics (NUTS), as regards the transmission of the time series for the new regional breakdown, Official Journal of the European Union. <http://www.stat.si/doc/reg/NUTS_1046_2012_ EN.pdf> (02.03.2015)

European Commission (ed.) (2013), European Commission communicates, Response of Algirdas Šemeta on behalf of the Commission on Romania's regionalisation process, 15 July 2013. $<$ http://www.europarl.europa.eu/sides/getDoc.do?pubRef=-//EP//TEXT+WQ+E-2013$008653+0+\mathrm{DOC}+\mathrm{XML}+\mathrm{V} 0 / / \mathrm{EN} \&$ language $=\mathrm{en}>(27.08 .2014)$

European Union (ed.) (2003), Regulation No. 1059/2003 of the European Parliament and of the Council of 26 May 2003 on the establishment of a common classification of territorial units for statistics (NUTS), Official Journal of the European Union. <http://eur-lex.europa. eu/LexUriServ/LexUriServ.do?uri=OJ:L:2003:154:0001:0041:EN:PDF> (02.03.2015)

FilitTi I.C. (1929), Despre vechea organizare administrativă a Principatelor Române. In: Revista de Drept Public, 4, 2.

Gherman S. (1998), M-am săturat de România! Monitorul de Cluj, 16 September 1998, $<$ http://www.scribd.com/doc/225613426/Sabin-Gherman-M-Am-Saturat-de-Romania $>$ (05.07.2014)

Government of Romania, European Commission (eds.) (1997), Green Paper. Regional Development Policy in Romania. Bucharest.

Government of Romania, European Union, PHare Programme (eds.) (1997), Regional Development Policy in Romania. Conference Proceedings. Bucharest.

Groza O., Munetele I., Țurcănașu G., Rusu A., Boamfă I. (2008), Atlas teritorial al României: instrument de analiză teritorială. Iaști, CUGUAT-TIGRIS. <http://www.mdrl.ro/_docu mente/atlas/atlas.htm $>(02.03 .2015)$

Gusti D., Orghidan C. Vulcănescu M., Leonte V., Buzatu Gh. (eds.) (1938), Enciclopedia României, Vol II. Țara Românească. București, Imprimeria Națională. Retrieved from $<$ http://www.cimec.ro/pdf/enciclopedia-romaniei/dl.asp?filename=enciclopediaromaniei-vol-II-1938.pdf $>$

Hendriks F., Lidström A., Loughlin J. (eds.) (2010), The Oxford Handbook of Local and Regional Democracy in Europe. New York, Oxford University Press.

Hitchins K. (2013a), Românii 1774-1866. București, Humanitas.

Hitchins K. (2013b), România 1866-1947. București, Humanitas.

Hughes J., SAsse G., Gordon C. (2005), Europenization and Regionalisation in the EU's Enlargement to Central and Eastern Europe: The Myth of Conditionality. New York, Palgrave Macmillan.

IAnoș I., PAScariu G. (2012), Începuturile politicii regionale în România. In: Urbanismul serie nouă, 11 , pp. 74-79.

IoRDAn I. (2003), România, încotro? Regionalizare, Cum? Când? Structuri administrativteritoriale în România. București, CD Press.

IoRDAN I., AleXANDRESCu V. (1996), Consideraţii geografice privind reorganizarea administrativă a teritoriului României. In: Revista Geografică, II-III, pp. 118-121.

Keating M. (2009), Rescaling Europe. In: Perspectives on European Politics and Society, 10, 1, pp. 34-50.

KING R. (1973), Minorities under communism: nationalities as a source of tension among Balkan Communist states. Cambridge, Harvard University Press. 
Kiss T., Barna G. (2012), Népszámlálás 2011. Erdélyi magyar népesedés a XXI. század első évtizedében. Cluj-Napoca, Romanian Institute for Research on National Minorities.

Kocsis K. (ed.) (2007), South Eastern Europe in Maps. Budapest, Hungarian Academy of Sciences - Geographical Institute.

KöPECZI B. (ed.) (1987), Erdély története I, II, III. Budapest, Akadémiai Kiadó.

KovÁcs Cs. (2011), Geopolitikai helyzet és közigazgatási földrajz. In: BenEdEK J. (ed.), Románia: tér, gazdaság, társadalom, pp. 57-79. Kolozsvár, Nemzeti Kisebbségkutató Intézet - Kriterion.

Lefter C., Constantin C. (2009), Economic and Social Disparities of Romania in Regional and County Profile. In: Management and Marketing, 4, 1, pp. 77-96.

Lovatt C. (1999), The Mioritic Space: Romanian National Identity in the Work of Lucian Blaga. In: Central Europe Review, 1, 18. <http://www.ce-review.org/99/18/lovatt18.html> (02.03.2015)

MiHĂILeSCU G. (2013), Dosarul regionalizării - o mimare a democrației? Contributors. Retrieved from $\quad<\mathrm{http}: / /$ www.contributors.ro/economie/dosarul-regionalizarii-\%E2\%80\%93-omimare-a-democratiei/> (02.03.2015)

Moldoveanu M.D. (1934), Harta României: fizică-administrativă și turistică. București. Retrieved from the map collection of the Cholnoky Jenő Geographic Society, <http:// hagyatek.cholnoky.ro/>

Murgescu B. (2010), România și Europa. Acumularea decalajelor economice (1500-2010). București, Polirom.

NACU A. (2012), Organizarea administrativă a României în Perioada Interbelică și în anii celui De-al Doilea Război Mondial (1919-1945). <http://earth.unibuc.ro/file_download/29334> (06.09.2014)

Nemes-Nagy J. (2009), Terek, helyek, régiók: a regionális tudomány alapjai. Budapest, Akadémiai Kiadó.

Nistor I. (2000), Comuna și județul. Factori ai civilaziției românești unitare: evoluție istorică. Cluj-Napoca, Editura Dacia.

NovÁK Cs. (2005), A megyésítés előkészítése és a nemzetiségi kérdés Romániában (1968). In: BÁRDI N., SiMON A. (eds.), Integrációs stratégiák a magyar kisebbségek történetében, pp. 405-421. Somorja, Fórum Kisebbségkutató Intézet.

OroveANu M. (1986), Organizarea administrativă și sistematizarea teritoriului R.S. România. București, Editura Științifică și Enciclopedică.

PAASI A. (2009), The resurgence of the 'Region' and 'Regional Identity': theoretical perspectives and empirical observations on regional dynamics in Europe. In: Review of International Studies, 35, S1, pp. 121-146.

PAASI A. (2010), Regions are social constructs, but who or what 'constructs' them? In: Environment and Planning, 42, pp. 2296-2301.

PAASI A. (2011), The region, identity, power. In: Procedia of Social and Behavioral Sciences, 14, pp. 9-16.

PAASI A. (2013), Regional Planning and the Mobilization of 'Regional Identity': From Bounded Spaces to Relational Complexity. In: Regional Studies, 47, 8, pp. 1206-1220.

RAmbøll (1996), Disparități regionale în România 1990-1994. București, Programul PHARE.

RandMcNally \& Company (ed.) (1897), Atlas of the World. Chicago,. Retrieved from David Rumsey's Map Collection $<$ http://www.davidrumsey.com/> 
Romsics I. (ed.) (2011), Magyarország története. Budapest, Akadémiai Kiadó.

SĂGEATĂ R. (2006), Deciziile politico-administrative și organizarea teritoriului: studiu geografic cu aplicare la teritoriul României. București, Editura Universității Naționale de Apărare 'Carol I'- Editura Top Form.

SĂGEATǍ R. (2011), The administrative-political function of human settlements and the role it plays in organizing geographical space. Case study - Romania. In: Human Geographies, 5, 1, pp. 77-94.

SĂGEATĂ R. (2012a), Acte normative care au vizat organizarea administrativ-teritorială din România (1859-2011). In: Urbanismul serie nouă, 11, pp. 20-21.

SĂGEATĂ R. (2012b), Organizarea administrativ-teritorială a României. Modelul interbelic. In: Urbanismul serie nouă, 11, pp. 67-70.

SĂGEATĂ R. (2013), Organizarea administrativ-teritorială a României. Evoluție, propuneri de optimizare, Retrieved from <http://regionalizare.mdrap.ro/2013/04/18/organizarea-ad ministrativ-teritoriala-a-romanieir-sageata/>

SANDu D. (2011), Social Disparities in the Regional Development and Policies of Romania. In: International Review of Social Research, 1, 1, pp. 1-30.

Schöpflin Gy. (1979), A magyarok helyzete Romániában. In: Kende P. (ed.), Párizsi Magyar Füzetek, 5, pp. 23-71. Paris, Dialogues Européens.

Steinherr A., Gros D. (1995), Winds of Change: Economic Transition in Central and Eastern Europe. New York, Longman.

Storciu V. (2012), Austerity and Structural Reforms in Romania: Severe Measures, Questionable Economic Results and Negative Social Consequences. International Policy Analysis, Friedrich Ebert Stiftung. Retrieved from <http://library.fes.de/pdf-files/id-moe/09310. pdf $>(13.11 .2014)$

Szabó T. (2014), Regionalisierung in Rumänien: Ideen, Entwürfe und Perspektiven. In: Studia Universitatis Babeș-Bolyai Studia Europaea, 59, 2, pp. 39-63.

Szöcs G. (2000), M-am săturat de România! Fragmente din reacţiile apărute în presă în perioada 16 septembrie 1998 - 1 decembrie 1999. Cluj-Napoca, Editura Curierul Transilvan (Erdélyi Híradó).

TAtur M. (2004), The Making of Regions in Post-Socialist Europe - the Impact of Culture, Economic Structure and Institutions. Vol. I-II. Wiesbaden, VS Verlag für Sozialwissenschaften.

Tomaney J. (2009), Region. In: Kitchin R., Nigel T. (eds.), International Encyclopedia of Human Geography. London, Elsevier.

Union of Soviet Socialist Republics, Chief Administration of Geodesy and Cartography under the Council of Ministers of the USSR (ed.) (1967), Atlas Mira, $2^{\text {nd }}$ edition. Moskva. Retrieved David Rumsey's Map Collection <http://www.davidrumsey.com/> (14.09.2014)

VAnghele O. (2010), Băsescu: Statul este un om foarte gras cocoţat în spatele unuia slab şi subţirel, care este economia. Mediafax, 6 March 2010, <http://www.mediafax.ro/politic/ basescu-statul-este-un-om-foarte-gras-cocotat-in-spatele-unuia-slab-si-subtirel-careeste-economia-6097010> (10.09.2014) 